\title{
The Characterization of Amylolytic Enzyme Present in Fermented Sweet Sap of Palmyrah
}

\author{
Arumugam Vengadaramana*, Mehala Uthayasooriyan, Thananthika Sittampalam, Nirosha Razeek, Ranganathan \\ Kapilan
}

Department of Botany, Faculty of science, University of Jaffna, Sri Lanka.

\section{ARTICLE INFO \\ Article history: \\ Received on: $28 / 02 / 2016$ \\ Revised on: $28 / 03 / 2016$ \\ Accepted on: 11/04/2016 \\ Available online: $21 / 06 / 2016$}

Key words

Amylase, enzyme activity, enzyme stability, starch, zero order kinetics.

\begin{abstract}
Amylase enzyme obtained from $12 \mathrm{~h}$ of naturally fermented sweet sap of palmyrah. The amylase showed zero order kinetics for $10 \mathrm{~min}$. The optimum temperature for the activities of enzyme as $65^{\circ} \mathrm{C}$ and $\mathrm{pH}$ was 7.0 . When

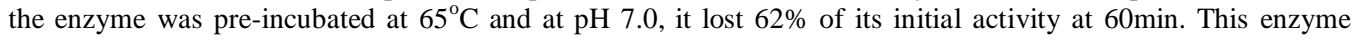
showed activity with starch, lactose, maltose, pectin and sucrose. Amylase activity was strongly inhibited by $2 \mathrm{mM}$ of $\mathrm{Hg}^{2+}$ but $2 \mathrm{mM}$ of $\mathrm{Ca}^{2+}, \mathrm{Ba}^{2+}, \mathrm{Mg}^{2+}, \mathrm{Mn}^{2+}, \mathrm{Na}^{+}, \mathrm{Zn}^{2+}, \mathrm{Mn}^{2+}$ and $\mathrm{Cu}^{2+}$ stimulated the enzyme activity at $65^{\circ} \mathrm{C}$ and at $\mathrm{pH} 7.0$. The enzyme in the presence of $2 \mathrm{mM} \mathrm{Mn}{ }^{2+}, \mathrm{Cu}^{2+}$ and $\mathrm{Na}^{+}$separately, retained 79,86 and 68 $\%$ of its initial activity respectively at $60 \mathrm{~min}, 65^{\circ} \mathrm{C}$ and $\mathrm{pH} 7.0$.
\end{abstract}

\section{INTRODUCTION}

Amylolytic enzymes form a large group of enzymes operating on starch and related oligo- and polysaccharides. The three best known amylases are $\alpha$-amylase, $\beta$-amylase and glucoamylase (rarely $\gamma$-amylase). The amylases of microorganisms have a broad spectrum of industrial applications as they are more stable than when prepared with plant and animal amylases [1]. The major advantage of using microorganisms for the production of amylases is the economical bulk production capacity and the fact that they are easily manipulated to obtain enzymes of desired characteristics [2]. Amylases are derived from several fungi, yeasts and bacteria [3, 4, 5 and 6]. Unfermented sweet sap of palmyrah (Borassus flabellifer) palm commonly referred to as 'sweet toddy' contains $10-16.5 \% \mathrm{w} / \mathrm{v}$ sugar, mainly in the form of sucrose [7], vitamins and minerals forms a good culture medium for the microorganisms to grow. The crude sugar (jaggery) in Sri Lanka is mainly obtained from the sweet sugary sap obtained from the tapped inflorescence of the Coconut (Cocos nucifera), Palmyrah

* Corresponding Author

A.Vengadaramana, Senior lecturer, Department of Botany, Faculty of science, University of Jaffna, Sri Lanka. Phone 0094777110998,

E.mail-avengad19@yahoo.com orvengad@jfn.ac.lk
(Borassus flabellifer) and Kithul (Caryota urens) palms [8] The microorganisms usually seen in Palmyrah toddy are yeast (mostly Saccharomyces cerevisiae, S. chevalieri, Kloeckere apiculata, Schizosaccharomyces pombe) and bacteria (Bacillus cereus, B. sphericus, B. firmus). Fermented sweet sap of palmyrah (Toddy) is the natural fermented sap and contains about 5-6\% (w/v) ethanol during taping of the sap. The objectives of this study were to extract amylolytic enzyme from naturally fermented sweet sap of palmyrah palm and characterization of the amylolytic enzyme.

\section{MATERIALS AND METHODS}

\subsection{Source of amylolytic enzyme}

Palmyrah palms growing widely in Jaffna district of Sri Lanka was selected. Matured palm trees were chosen randomly in six different areas of the Jaffna district. Tips of young inflorescence of the palm trees were tapped and sterile, clean collecting pots were fixed. After 18 hours of collection of palmyrah sweet sap the samples were transferred to sterile bottles and brought to laboratory of department of botany, university of Jaffna. $100 \mathrm{~mL}$ of sugary sap were transferred to $500 \mathrm{~mL}$ of Erlenmeyer flasks and allowed to natural ferment for $12 \mathrm{~h}$ at room temperature $(29 \pm 3)$ with shaking at $100 \mathrm{rpm}$. The filtrates were used as source of amylolytic enzyme sample. 


\subsection{Measurement of amylase activity}

Soluble starch $\left(2 \mathrm{gL}^{-1}\right)$ in $0.01 \mathrm{M}$ phosphate buffer $(\mathrm{pH} 7.0)$ was pre incubated for $3 \mathrm{~min}$ at $65^{\circ} \mathrm{C}$. Then $0.5 \mathrm{~mL}$ of the enzyme sample was mixed with $0.5 \mathrm{~mL}$ substrate and incubated for $5 \mathrm{~min}$ at $65^{\circ} \mathrm{C}$. Reducing sugar was measured by the DNS method [9]. One unit of amylase activity is defined as the amount of enzyme that produces one Mole of reducing sugar in one minute at $65^{\circ} \mathrm{C}$, and pH 7.0 from soluble starch $\left(20 \mathrm{gL}^{-1}\right)$ as substrate.

\subsection{Effect of time}

Soluble starch $\left(0.5 \mathrm{~mL}, 20 \mathrm{gL}^{-1}\right.$ in phosphate buffer $\mathrm{pH}$ 7.0) was allowed to react with amylase enzyme sample $(0.5 \mathrm{~mL})$ at $65^{\circ} \mathrm{C}$ and the amount of glucose produced was monitored. The time suitable for the incubation was optimized.

\subsection{Effect of temperature}

The effect of temperature on enzyme sample was determined by incubating enzyme for optimized time with $0.5 \mathrm{~mL}$ of soluble starch $\left(20 \mathrm{gL}^{-1}\right)$ at different temperatures, varied from 30 to $75^{\circ} \mathrm{C}$. Then activities of the enzyme samples were measured and relative activities were calculated.

\subsection{Effect of $\mathbf{p H}$}

The effect of $\mathrm{pH}$ on activity of enzyme sample was measured by preparing $20 \mathrm{gL}^{-1}$ soluble starch in buffers of different $\mathrm{pH}$ values ranging from 4.0 to 10.0 (for $\mathrm{pH}$ from 4.0 to 6.0 citrate phosphate buffer, for $\mathrm{pH} 8.0$ Tris buffer, for $\mathrm{pH} 9.0$ glycine $\mathrm{NaOH}$ buffer and for $\mathrm{pH} 10.0$ carbonate, bicarbonate buffer were used). Enzymes were incubated at optimized temperatures for optimized period at $65^{\circ} \mathrm{C}$.

\subsection{Stability of enzymes with temperature}

Amylolytic enzyme was pre-incubated at $65^{\circ} \mathrm{C}$ and at $\mathrm{pH}$ 7.0 and the activities of the enzymes were monitored.

\subsection{Substrate specificity of the enzyme}

Starch, Lactose, Maltose, Pectin and Sucrose of $20 \mathrm{gL}^{-1}$ concentration in $0.01 \mathrm{M}$ phosphate buffer $(\mathrm{pH} 7.0)$ were prepared and were used as substrates. The activities of the amylolytic enzymes were determined at $65^{\circ} \mathrm{C}$.

\subsection{Effect of cations on the activity and stability of the enzyme}

To determine the effect of $2 \mathrm{mM}$ cations such as $\mathrm{Zn}^{2+}$, $\mathrm{Ba}^{2+}, \mathrm{Mg}^{2+}, \mathrm{Mn}^{2+}, \mathrm{Na}^{+}, \mathrm{Hg}^{2+}, \mathrm{Ca}^{2+}$ and $\mathrm{Cu}^{2+}$ on the activity of amylase from fermented sweet sap of palmyrah $2 \mathrm{mM}$ ions $\left(\mathrm{Ca}^{2+}\right.$, $\mathrm{Mg}^{2+}, \mathrm{Na}^{+}, \mathrm{Hg}^{2+}, \mathrm{Mn}^{2+}, \mathrm{Zn}^{2+}$ and $\mathrm{Ba}^{2+}$ in the form of chlorides and $2 \mathrm{mM} \mathrm{Cu}^{2+}$ in the form of sulphate) enzyme solutions were prepared separately and the enzyme activities were measured.

To determine the thermal stability of enzyme containing $2 \mathrm{mM} \mathrm{Mn}^{2+}, \mathrm{Cu}^{2+}$ and $\mathrm{Na}^{+}$were pre incubated separately at $65^{\circ} \mathrm{C}$ for 1 hour and the enzyme activity were monitored.

\section{RESULTS AND DISCUSSION}

The phloem sap of Palmyrah palm (Borassus flabellifer) contains many nutrients such as nitrogen, protein, sugars, minerals as ash phosphorus, iron, vitamin C, vitamin BI [10] therefore it is an ideal medium for the growth of microorgansms. Its neutral $\mathrm{pH}$ favours the growth and multiplication of bacteria. Initially the fermenting sweet sap had a bacteria count around 124 cells $/ \mathrm{mL}$, while the yeast cell count was 56 cells $/ \mathrm{mL}$. After natural fermentation at 100rpm and roomtemperature $(29 \pm 3)$ for 12 hours, the yeast cell count increased up to 136 cells $/ \mathrm{mL}$ while the bacteria count decreased to 73 cells $/ \mathrm{mL}$. Similar microbial changes had been observed in the cocount sap [11], Kithul palm [12] and palm wines [13] during natural fermentation.

Today a large number of microbial amylases are available commercially and they have almost completely replaced chemical hydrolysis of starch in starch processing industry. Several yeast strains produce amylolytic enzyme under different fermentation conditions [14, 15 and 16]. In our study presence of amylolytic enzyme in fermented sweet sap of palmyrah was confirmed by measuring the activity of amylase enzyme. The amylase enzyme production could be due to activity of yeast cells.

\subsection{Effect of time}

The influence of incubation time on the production of glucose from the reaction of amylase with starch $\left(20 \mathrm{gL}^{-1}\right)$ was studied for $1 \mathrm{~h}$ at $\mathrm{pH} 7.0$ and $65^{\circ} \mathrm{C}$. Amylase preparations showed a linear relationship between the time and production up to 10minutes. Hence, it was decided to fix the reaction time for $5 \mathrm{~min}$.

\subsection{Effect of temperature on the activity of amylase enzyme}

The initial relative activity of amylase increased to $100 \%$ as the temperature increased up to $65^{\circ} \mathrm{C}$ (Fig. 1). Maximum activity was obtained at $65^{\circ} \mathrm{C}$ and $\mathrm{pH} 7.0$ for the substrate starch $\left(20 \mathrm{gL}^{-1}\right)$. Above $65^{\circ} \mathrm{C}$, amylase activity was decreased sharply due to thermal denaturation of the enzyme and lost the activity. Hence $65^{\circ} \mathrm{C}$ was chosen as the optimum temperature for the assay of amylases. The purified $\alpha$-amylase of Bacillus licheniformis CUMC 305 showed maximal activity at $90^{\circ} \mathrm{C}$ and $\mathrm{pH} 9.0$ [17].

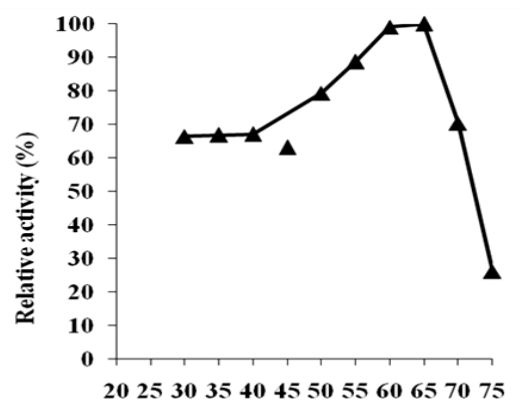

Temperature $\left({ }^{\circ} \mathrm{C}\right)$

Fig. 1: Effect of temperature on the activity of amylase from fermented sweet sap of palmyrah with starch $\left(20 \mathrm{gL}^{-1}\right)$ at $\mathrm{pH}$ 7.0. Amylases activities were measured at different temperatures using $20 \mathrm{gL}^{-1}$ starch as substrate by incubating for $5 \mathrm{~min}$ at $\mathrm{pH} 7.0$. 


\subsection{Effect of pH on the activity of amylases}

When the $\mathrm{pH}$ was increased, the maximum activity of amylases was obtained at pH 7.0 (Fig. 2). The dependence of enzyme activity on $\mathrm{pH}$ is a consequence of the amphoteric properties of proteins [18].

\subsection{Substrate specificity of the amylases}

Different substrates were hydrolyzed by amylase enzyme. When $20 \mathrm{gL}^{-1}$ of lactose, maltose, pectin and sucrose were used as substrates to amylase enzyme that showed 168, 138, 74 and $55 \%$ of relative activity (Table 1 ) when compared to soluble starch at $65^{\circ} \mathrm{C}$ and $\mathrm{pH} 7.0$.

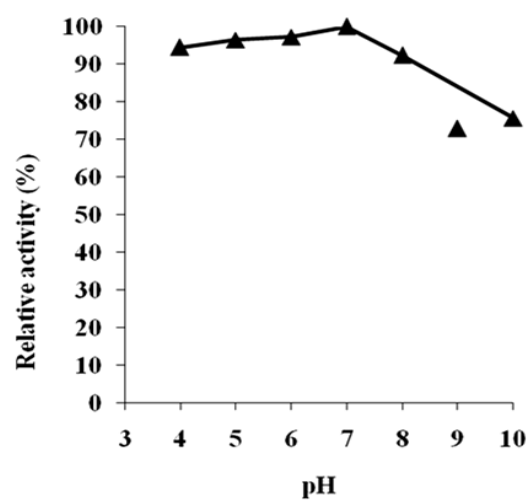

Fig. 2: Effect of $\mathrm{pH}$ on the activity of amylase from fermented sweet sap of palmyrah with starch $\left(20 \mathrm{gL}^{-1}\right)$ at $\mathrm{pH} 65^{\circ} \mathrm{C}$. Activities were measured at different $\mathrm{pH}$, using $20 \mathrm{gL}^{-1}$ starch as substrate by incubating for at 5 minutes at $65^{\circ} \mathrm{C}$.

Table 1: Effect of different carbon sources on the activity of amylase from fermented sweet sap of palmyrah. Amylase activity was determined at $65^{\circ} \mathrm{C}$ and $\mathrm{pH} 7.0$ using $20 \mathrm{gL}^{-1}$ different substrate by incubating for at $5 \mathrm{~min}$.

\begin{tabular}{ll}
\hline Substrate $\left(\mathbf{2 0} \mathbf{g L}^{-1}\right)$ & Relative amylase activity $\mathbf{( \% )}$ \\
\hline Starch & 100 \\
Lactose & 168 \\
Maltose & 138 \\
Pectin & 74 \\
Sucrose & 55 \\
\hline
\end{tabular}

The relative rates of hydrolysis of amylase, soluble starch, amylopectin and dextrin by $\alpha$-amylase from Bacteroides amlophilus were 100, 97, 92 and 60\% respectively [19]. Krishnan et al [17] showed that the substrate specificity of purified Alphaamylase from Bacillus licheniformis CUMC305 with different 1\% substrates, release of reducing sugar were very rapid from amylase (129\%) but was slower from soluble starch (101.4\%), amylopectin $(58.3 \%)$ and glycogen (100\%). Alpha-amylase from Bacillus licheniformis ATCC 6346, exhibited no activity with pullulan and hydrolysis of amylose, starch and amylopectin were 119.3, 100 and $77.7 \%$ respectively [20]. Starch, amylase and amylopctin were the substrates preferentially hydrolysed by a-amylase from Aspergillus tamari [21].

\subsection{Effect of temperature on the stability of amylase}

When the amylase enzyme was pre-incubated at $65^{\circ} \mathrm{C}$ and $\mathrm{pH} 7,97 \%$ of its initial activity was retained for $10 \mathrm{~min}$ and lost $62 \%$ of its original activity at $60 \mathrm{~min}$ (Fig.3).

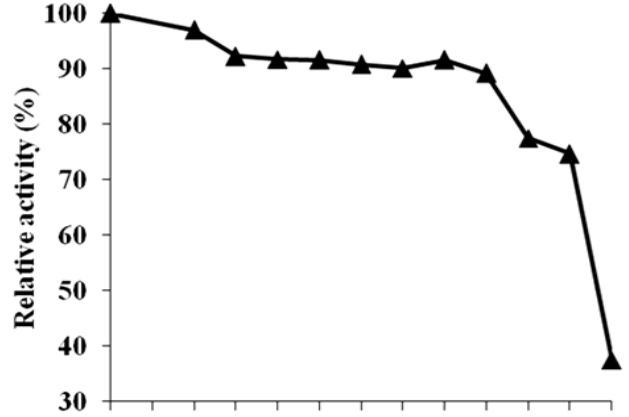

$\begin{array}{llllllllllllll}00 & 05 & 10 & 15 & 20 & 25 & 30 & 35 & 40 & 45 & 50 & 55 & 60\end{array}$

Time (min)

Fig. 3. Effect of of Temperature on the stability of amylase from fermented sweet sap of palmyrah. Amylase activity was measured at $65^{\circ} \mathrm{C}$ using $20 \mathrm{gL}^{-1}$ starch as substrate and incubating for $5 \mathrm{~min} \mathrm{pH}$ at 7.0.

\subsection{Effect of cations on the activity and stability of amylase}

The effect of $2 \mathrm{mM} \mathrm{Ca}{ }^{2+}, \mathrm{Ba}^{2+}, \mathrm{Mg}^{2+}, \mathrm{Mn}^{2+}, \mathrm{Na}^{+}, \mathrm{Hg}^{2+}$, $\mathrm{Zn}^{2+}, \mathrm{Mn}^{2+}$ and $\mathrm{Cu}^{2+}$ on amylase activity are presented in Table 1 . In the presence of $\mathrm{Mn}^{2+}, \mathrm{Cu}^{2+}, \mathrm{Ba}^{2+}, \mathrm{Zn}^{2+}$ and $\mathrm{Na}^{+}$, the enzyme showed higher activity at $65^{\circ} \mathrm{C}$ and $\mathrm{pH}$ 7.0. A slight increase in enzyme activity was produced by $\mathrm{Mg}^{2+}$ and stronger inhibition by $\mathrm{Hg}^{2+}$ (Table 2). Amylase of soybean seeds exhibited marked activating effects on the activity in the presence of $2 \mathrm{mM}$ Cobalt (II) and Manganese (II), enhancing up to $200 \%$ of the initial activity while Mercury (II) ions severely inhibited, however $\mathrm{K}^{+}$, $\mathrm{Ca}^{2+}, \mathrm{Mg}^{2+}, \mathrm{Al}^{3+}, \mathrm{CU}^{2+}, \mathrm{Zn}^{2+}$ and $\mathrm{Fe}^{3+}$ moderately increased the enzyme activity to a certain extent [22]. Presence of $\mathrm{Mn}^{2+}$ and $\mathrm{Fe}^{2+}$ enhanced the activity of alpha-amylase produced by Aspergillus oryzae and is almost doubled in presence of $\mathrm{Mn}^{2+}$ [23] and activity of $\alpha$-amylase from Bacillus licheniformis ATCC 6346 was strongly inhibited by $\mathrm{Cu}^{2+}, \mathrm{Hg} 2^{+}$and $\mathrm{Mn}^{2+}$ but less affected by $\mathrm{Mg}^{2+}$ and $\mathrm{Ba}^{2+} \cdot \mathrm{Ca}^{2+}$ and $\mathrm{Na}^{+}$stimulated the enzyme activity at 85 ${ }^{\circ} \mathrm{C}$ and at $\mathrm{pH} 7.0$ [24].

Table 2: Effect of different cations $(2 \mathrm{mM})$ on the activity of amylase from fermented sweet sap of palmyrah. Amylase activity was determined at $65^{\circ} \mathrm{C}$ and $\mathrm{pH} 7.0$ using $20 \mathrm{gL}^{-1}$ starch as substrate by incubating for at $5 \mathrm{~min}$.

\begin{tabular}{cc}
\hline Cations $(\mathbf{2} \mathbf{~ m M})$ & Relative enzyme activity $(\%)$ \\
\hline $\mathrm{Control}^{2+}$ & 100 \\
$\mathrm{Ca}^{2+}$ & 136 \\
$\mathrm{Ba}^{2+}$ & 124 \\
$\mathrm{Mg}^{2+}$ & 119 \\
$\mathrm{Na}^{+}$ & 139 \\
$\mathrm{Hg}^{2+}$ & 003 \\
$\mathrm{Cu}^{2+}$ & 139 \\
$\mathrm{Zn}^{2+}$ & 136 \\
$\mathrm{Mn}^{2+}$ & 149 \\
\hline
\end{tabular}

When amylase containing $2 \mathrm{mM}$ of $\mathrm{Mn}^{2+} \mathrm{Cu}^{2+}$ and $\mathrm{Na}^{+}$ was incubated separately at $\mathrm{pH} 7.0$ and $65^{\circ} \mathrm{C}$, amylase showed a higher stability in the presence of $\mathrm{Cu}^{2+}$ than control and the presence of other two ions (Fig. 4). When amylase was preincubated in the presence of $2 \mathrm{mM}$ of $\mathrm{Mn}^{2+} \mathrm{Cu}^{2+}$ and $\mathrm{Na}^{+}$ seperately, the enzyme activity was retained at 79, 86 and $68 \%$ respectively at $60 \mathrm{~min}$ but in the absence of cations (Control) enzyme retained $38 \%$ of its initial activity at $60 \mathrm{~min}$. 


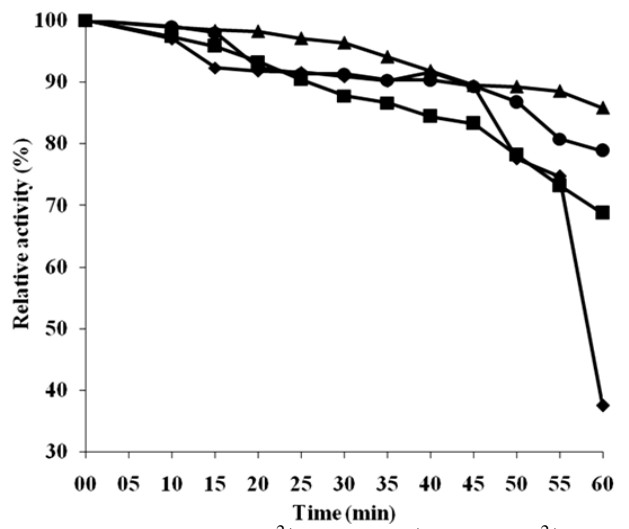

Fig. 4. Effect of $2 \mathrm{mM}$ of $(\bullet), \mathrm{Mn}^{2+} ;(\boldsymbol{\bullet}), \mathrm{Na}^{+} ;(\boldsymbol{\Delta}), \mathrm{Cu}^{2+}$ and (४), control (without addition of any ions) on the stability of amylase from fermented sweet sap of palmyrah at $65^{\circ} \mathrm{C}$. Amylase activity was measured at $65^{\circ} \mathrm{C}$ using $20 \mathrm{gL}^{-1}$ starch as substrate and incubating for $5 \mathrm{~min} \mathrm{pH}$ at 7.0.

\section{CONCLUSION}

The amylase enzyme produced by the activity of yeast cells during natural fermentation of sweet sap of palmyrah palms. Presence of $\mathrm{Ca}^{2+}, \mathrm{Ba}^{2+}, \mathrm{Mg}^{2+}, \mathrm{Mn}^{2+}, \mathrm{Na}^{+}, \mathrm{Zn}^{2+}, \mathrm{Mn}^{2+}$ and $\mathrm{Cu}^{2+}$ increases the activity and stability of the amylase enzyme.

\section{ACKNOWLEDGMENT}

Authors thank Jasothan, J.P Department of Botany, University of Jaffna for his kind support and the immense help

\section{REFERENCES}

1. Pandey A, Nigam P, Soccol CR, Soccol VT, Sing D, Mohan R. Advances in microbial amylases. Biotechnology and Applied Biochemistry. 2000; 31(2):135-152.

2. Lonsane BK, Ramesh MV. Production of bacterial thermostable $\alpha$ amylase by solid-state fermentation: a potentialtool for achieving economy in enzyme production and starch hydrolysis. Advances in Applied Microbiology. 1990, 35(1), 1-56.

3. Souza PM, Magalhaes PO. Application of microbial amylase in industry. Brazilian Journal of Microbiology. 2010; 41(4): 850-861.

4. Chi HLZ, Wang X, Duan X, Ma L, Gao L. Purification and characterization of extracellular amylase from the marine yeast Aureobasidium pullulans $\mathrm{N} 13 \mathrm{~d}$ and its raw potato starch digestion .Enzyme Microbiology and Technology. 2007; 40(5):1006-1012.

5. Liu XD, Xu Y. A novel raw starch digesting $\alpha$-amylase from a newly isolated Bacillus sp. YX-1: purification and characterization. Bioresearch Technology. 2008; 99(10): 4315-4320.

6. Gupta A, Gupta VK, Modi DR, Yadava LP. Production and characterization of $\alpha$-amylase from Aspergillus niger. Biotechnology. 2008; 7(3): 551-556.

7. Kumuthini RC, Theivendirarajah K. Palmyrah palm wine part II: Improvements in alcohol production. Journal of National Science Council Sri Lanka. 1988; 16(2): 147-157.

8. Kapilan R, Robika K, Subajini M, Srivijeindran S. Determination of Efficient Fermentation Inhibitor of Sweet Sap of Cocos Nucifera and Optimization of Concentration for Quality Outputs in Northern Sri Lanka. International Journal of Scientific Research in Agricultural Sciences. 2015; 2(7): 166-174.
9. Miller G. Use of dinitrosalisilic reagent for the determination of reducing sugars. Analitical Chemistry. 1959; 31: 426-428.

10. Davis TA, Johnson DV. Current utilization and further development of the palmyra palm (Borassus flabellifer L., Arecaceae) in Tamil Nadu State, India. Economic Botany. 1987; 41(2): 247-266.

11. Athputhrajah JD, Widanapathirana S, Samarajeewa U. Microbiology and biochemistry of natural fermentation of coconut palm sap. Food Microbiology. 1986; 3: 273-280.

12. Jeyatilake AN, Vijeyaratne SC. Biochemical and microbiological changes of Caryota urens (Kithul phalm) phloem sap. Vidyodaya Journal of Science. 1999; 8: 91-108.

13. Okafora N. Traditional Alcoholic Beverages of Tropical Africa: strategies for scale up. Process Biochemistry. 1990; 213-220.

14. Tansel HY. Isolation and Characterization of Amylase Producing Yeasts and Improvement of Amylase Production. Turkish Journal of Biochemistry. 2013; 38(1): 101-108.

15. Hostinova E. Amylolytic enzymes produced by the yeast Saccharomycopsis fibuligera. Biologia Brastislava. 2002; 11: 247-251.

16. Safri I, Kamara DS, Rachman SD, Fadhlillah IKM. Amylase production from the yeast Saccharomycopsis fibuligera and its potency for glucose production from raw starch. Proceeding of The International Seminar on Chemistry. 2008; 688-691.

17. Krishnan T, Chandra AK. Purification and characterization of alphaamylase from Bacillus licheniformis CUMC305. Applied Enviornmental Microbiology. 1983; 46: 430-437.

18. Williams BL, Wilson K. General principles of biochemical investigations. In : A biologist guide to principles of biochemical investigations. In: A biologist guide to principles and techniques of practical biochemistry. Eds. Williams, B.L. and K.Edward Arnold Publishers Ltd., London. 1983.

19. Steven J, Wethy MC, Haetman A. Purification and Some Properties of an Extracellular Alpha-Amylase from Bacteroides amylophilus. Journal of Bacteriology. 1977; 129(3): 1537-1544

20. Vengadaramana A, Balakumar S, Arasaratnam V. Purification and comparison properties of crude enzyme with purified $\alpha$-amylase from Bacillus licheniformis ATCC 6346. European Journal of Experimental Biology. 2011; 1(3): 58-69.

21. Fabiana GM, Veridiana L, Rosane MP. A thermostable maltosetolerant $\alpha$-amylase from Aspergillus tamari. Journal of Basic Microbiology. 2004; 44(1): 29-25.

22. Om Prakash, Nivedita J, Pandev RK. Effect of metal ions, EDTA and sulfhydryl reagents on soybean amylase activity. Asian Journal of Biochemistry. 2011; 6(3): 282-290.

23. Anil Kumar P, Nampoothiri KM, Ramachandran S, George S, Pandey A. Partial purification and characterization of $\alpha$-amylase produced by Aspergillus oryzae using spent-brewing strain. Indian Journal of Biotechnology. 2004; 4: 336-341.

24. Vengadaramana A, Balakumar S, Arasaratnam V. Stimulation of thermal stability of $\alpha$-amylase from Bacillus icheniformis ATCC 6346 by treating with cations. Ceylon Journal of Science (Bioscience.). 2012; 41 (1): 35-44.

\section{How to cite this article:}

Vengadaramana A, Uthayasooriyan M, Sittampalam T, Razeek N, Kapilan R. The Characterization of Amylolytic Enzyme Present in Fermented Sweet Sap of Palmyrah. J App Biol Biotech. 2016; 4 (03): 020-023. DOI: 10.7324/JABB.2016.40304 